\title{
Penerapan Rekayasa Nilai (Value Engineering) Pekerjaan Arsitektural Pada Proyek Pembangunan Transmart Carrefour Padang
}

\author{
Khaerul Bahri, dan Retno Indryani \\ Departemen Teknik Sipil, Fakultas Teknik Sipil, Lingkungan, dan Kebumian, Institut Teknologi \\ Sepuluh Nopember (ITS) \\ e-mail: retno_i@ce.its.ac.id
}

\begin{abstract}
Abstrak-Transmart Carrefour Padang merupakan gedung bertingkat enam lantai dengan luas total area bangunan sebesar $43.920 \mathrm{~m} 2$ dan biaya per $\mathrm{m} 2$ sebesar $\mathrm{Rp}$. 7.568.000,00. dengan nominal sebesar itu mengindikasikan gedung tersebut berbiaya tinggi sehingga perlu dilakukan efisisensi biaya. Upaya pengoptimalan anggaran biaya tanpa menghilangkan nilai fungsi salah satunya adalah dengan cara penerapan metode Rekayasa Nilai (Value Engineering). Penelitian ini bertujuan untuk untuk mengetahui besarnya total penghematan biaya yang dapat diperoleh setelah penerapan metode Rekayasa Nilai (Value Engineering). Metode yang dilakukan dalam penelitian ini adalah rencana kerja rekayasa nilai yang terbagi dalam 4 (empat) tahap yaitu : tahap informasi, tahap kreatif, tahap analisa dan tahap rekomendasi. Dalam tahap informasi dilakukan identifikasi item pekerjaan yang berpengaruh besar pada proyek dengan cara cost model dan perbandingan cost dengan worth. Dalam tahap kreatif dilakukan pengumpulan alternatif desain baru. Dalam tahap analisis menyeleksi alternatif desain dengan cara analisis Life Cycle Cost (LCC) dan Analitycal Hierarchy Process (AHP). Tahap rekomendasi melakukan perekomendasian desain baru dari alternatif desain terpilih. Hasil analisis Life Cycle Cost (LCC) didapat alternatif desain dengan biaya terendah pada pekerjaan lantai adalah alternatif 4 (A4) dan pada pekerjaan dinding luar adalah alternatif 3 (B3). Hasil Analitycal Hierarchy Process (AHP) dengan pertimbangan beberapa kriteria, terpilih alternatif desain yang direkomendasikan untuk desain pekerjaan lantai adalah alternatif 1 (A1) yang terdiri dari "plat lantai, screed $20 \mathrm{~mm}$ (mortar instan), marmer lokal $(60 \times 60 \mathrm{~cm})$, dan plint marmer". Sedangkan untuk pekerjaan dinding luar alternatif terbaik adalah alternatif 3 (B3) terdiri dari "pasangan panel bata ringan $10 \mathrm{~cm}$, groving, dan cat exterior". Total penghematan biaya konstruksi yang diperoleh sebesar Rp. 1,797,509,359 dari total biaya pekerjaan arsitektur (Rp. 62,837,567,773).
\end{abstract}

Kata Kunci- AHP, LCC, Penghematan Biaya, Rekayasa Nilai.

\section{PENDAHULUAN}

$\mathrm{P}$ ERTUMBUHAN penduduk yang terus berkembang menjadikan Kota Padang masuk sebagai tujuan wisata MICE (Meetings, Incentives, Conventions, and Exhibitiions). Dilihat dari bidang usaha potensial untuk perekonomian Kota Padang yang didominasi oleh kegiatan perdagangan, sehingga akan mendorong banyak developer property retail (Mall) masuk ke Kota Padang. Salah satunya adalah dibangun gedung Transmart Carrefour Padang yang merupakan konsep baru dengan memadukan berbagai fasilitas masyarakat dalam satu tempat yang dibangun diatas lahan seluas 8263 m2 yang berlokasi di Jln. Khatib Sulaiman-Padang. Gedung bertingkat enam lantai dengan luas total area bangunan sebesar 43.920 m2 menghabiskan biaya pembangunan Rp. 300 Milyar. Dengan pendanaan yang cukup besar itu diperlukan upaya optimasi dan efektifitas pendanaan agar tidak mengalami pembuangan dana untuk hal yang tidak diperlukan. Upaya pengoptimalan anggaran biaya tanpa menghilangkan nilai fungsi dapat dilakukan dengan penerapan metode Rekayasa Nilai (Value Engineering). Jika ditinjau dari harga per m2 nya, dengan luas bangunan Transmart Carrefour Padang sebesar $43.920 \mathrm{~m} 2$, maka didapat harga per m2 sebesar Rp. 7.568.000,00 dengan nominal sebesar itu mengindikasikann gedung tersebut berbiaya tinggi sehingga perlu dilakukan efisisensi biaya

Penelitian ini bertujuan untuk mengetahui total penghematan biaya yang dapat diperoleh setelah penerapan metode Rekayasa Nilai (Value Engineering) pada pekerjaan yang dilakukan rekayasa nilai hanya pekerjaan arsitektural pembangunan proyek Mall Transmart Carrefour Padang.

\section{URAIAN PENELITIAN}

\section{A. Definisi dan Konsep Rekayasa Nilai}

Menurut standar Society of American Value Engineers/SAVE [1], nilai (value) adalah sebuah pernyataan hubungan antara fungsi-fungsi dan sumber daya. Secara umum nilai (value) digambarkan melalui hubungan sebagai berikut:

Nilai (Value) $\approx$ Fungsi/Sumber Daya

Dimana fungsi diukur dalam kinerja yang dipersyaratkan oleh pelanggan, sedangkan sumber daya diukur dalam jumlah material, tenaga kerja, harga, waktu, dan nilai - nilai yang diperlukan untuk menyelesaikan fungsi tersebut.

B. Work (Job Plan) Activities

1. Tahap Informasi

Menurut Zimmerman [2], tahap informasi dalam value engineering ditunjukkan untuk mendapatkan informasi seoptimal mungkin dari tahap desain suatu proyek.

2. Tahap Analisis Fungsi

Menurut Dell' Isola [3], fungsi suatu barang dan jasa merupakan jawaban atas "dapat melakukan apa benda, barang, jasa tersebut”. Dimana fungsi dalam value engineering ada dua yaitu: 
a. Fungsi primer, fungsi yang mendasari dasar diadakannya barang atau jasa tersebut, fungsi ini untuk menjawab pertanyaan “apa yang harus dilakukan” oleh barang atau jasa tersebut.

b. Fungsi sekunder yaitu fungsi yang sangat situasional serta kondisional dan bergantung pada pembeli dan pemanfaatannya.

3. Tahap Kreatif

Kegiatan-kegiatan umum yang dilakukan pada tahap ini adalah [1]:

a. Melakukan latihan pemanasan kreatif.

b. Menetapkan peraturan-peraturan yang melindungi lingkungan kreatif yang dikembangkan. Tools yang digunakan: Creativity "Ground Rules".

c. Menggunakan teknik stimulasi ide yang dapat meningkatkan nilai. Tools yang digunakan: Brainstroming, Gordon Technique, Nominal Group Technique, TRIZ, Synetics.

d. Mengembangkan ide alternatif yang dapat meningkatkannilai.

4. Tahap Evaluasi

Kegiatan-kegiatan umum yang dilakukan pada tahap ini adalah [1]:

a. Menjelaskan dan mengkategorikan setiap ide untuk mengembangkan sebuah pemahaman.

b. Mendiskusikan bagaimana ide-ide berdampak pada biaya proyek, dan kinerja parameter-parameter. Tools yang digunakan: T-Charts.

c. Memilih dan memprioritaskan ide-ide untuk pengembangan selanjutnya. Tools yang digunakan: Pugh Analysis, Kepner-Tregoe, Life Cycle Coasting.

Menjelaskan bagaimana ide-ide dituliskan sebagai standalone risk-reward invesment proposals

5. Tahap Pengembangan

Analisa pemilihan alternatif adalah analisa terakhir yang dilakukan dalam rangkaian kerja rekayasa nilai, dimana alternatif dinilai dengan menggunakan metode Analysis Hierarchy Process (AHP).

Metode AHP ini memiliki beberapa tahapan yang perlu dilakukan sebelum melakukan analisa [4], yaitu :

a) menentukan tujuan AHP secara keseluruhan.

b) Menentukan faktor yang berperan dalam pengambilan keputusan (decision making)

c) Menentukan kriteria yang perlu dipertimbangkan untuk mencapai tujuan (goal).

d) Menentukan subkriteria yang berada di tingkat bawah setelah kriteria.

e) Menentukan alternatif yang digunakan untuk mencapai tujuan.

6. Tahap Rekomendasi

Menurut Dell'Isola [5], dalam tahap ini ada tiga hal yang harus dilakukan, yaitu:

a. Meninjau semua solusi alternatif yang diajukan dengan sangat hati-hati dan mendetail untuk meyakinkan bahwa nilai yang tinggi dan penghematan yang signifikanlah yangbenar-benar ditawarkan.

Pada tahapan ini disampaikan rangkuman hasil analisa serta b. Proposal yang dibuat untuk pihak managemen proyek harus bagus dan akurat.

Mempresentasikan sebuah rancangan untuk mengimplementasikan.

\section{METODOLOGI}

\section{A. Tahapan Pengerjaan}

Langkah-langkah penelitian secara garis besar dijelaskan sebagai berikut:

1. Penyusunan Latar Belakang

Menjelaskan mengenai semua hal yang melatar belakangi.

2. Perumusan Masalah

Mengidentifikasi masalah yang akan diselesaikankan.

3. Studi Literatur

Pada tahapan ini dilakukan studi atau mempelajari literatur yang berkaitan dan mendukung.

4. Pengumpulan Data

Mengumpulkan data-data yang diperoleh dari konsultan perencana dan kontraktor untuk dilakukan analisa, yaitu berupa gambar desain perencanaan, Rencana Kerja Syarat (RKS), Rencana Anggaran Biaya (RAB), dan daftar harga bahan \& material yang diproleh dari brosur atau jurnal harga material untuk menghitung biaya alternatif yang dipilih.

5. Tahap informasi

Pada tahap ini dilakukan identifikasi item pekerjaan berbiaya tinggi dengan cara menyusun bagan cost breakdown structure, kemudian diurutkan dari biaya tertinggi hingga terendah kedalam tabel cost model lalu di plotkan pada grafik distribusi pareto untuk mengetahui item pekerjaan apa yang menghabiskan $20 \%$ biaya. Setelah itu dilakukan analisa fungsi untuk item pekerjaan berbiaya tinggi dari analisa sebelumnya. Pada tahapan analisa fungsi akan dilakukan perbandingan nilai cost dengan worth (C/W), apabila didapat nilai C/W > 2 maka item pekerjaan tersebut mengindikasikan bahwa memiliki biaya yang tidak perlu.

6. Tahap Kreatif

Pada tahap ini dilakukan pengumpulan alternatif desain baru dari masing-masing item pekerjaan yang memiliki nilai $\mathrm{C} / \mathrm{W}>2$. Pengumpulan alternatif dilakukan dengan teknik brainstorming, survey internet, dan diskusi dengan pihak yang berpengalaman.

7. Tahap Analisis

Pada tahapan ini dilakukan dua macam analisa. Yang pertama yaitu analisa biaya daur hidup, dimana setiap alternatif desain dari masing-masing pekerjaan dihitung biaya daur hidupnya (Life Cycle Cost Analysis/LCC). Yang kedua yaitu Analysis Hierarchy Proses/AHP. AHP digunakan untuk memilih atau menyeleksi alternatif desain mana yang akan direkomendasikan untuk digunakan.

8. Tahap Rekomendasi

Pada tahap rekomendasi dilakukan pelaporan dan perekomendasian desain baru dari alternatif desain terpilih. 9. Kesimpulan menjawab perumusan masalah yang mendasari tujuan 
dilakukannya penelitian ini, yaitu menyebutkan item pekerjaan yang perlu dilakukan rekayasa nilai, menjelaskan alternatif desain terbaik, serta memaparkan besarnya penghematan yang didapat dari rekayasa nilai terhadap item pekerjaan terpilih

\section{PENERAPAN REKAYASA NILAI}

\section{A. Identifikasi Item Berbiaya Tinggi Pekerjaan Arsitektural}

Dari Breakdown Cost Model ditinjau item yang termasuk pada pekerjaan arsitektur, selanjutnya diurutkan dari item dengan berbiaya tertinggi ke biaya terendah untuk memudahkan mengetahui pekerjaan mana yang paling mempengaruhi proyek. Adapun bentuk dari Cost Model terdapat pada Tabel 1.

Tabel 1.

Cost Model

\begin{tabular}{|r|l|l|l|}
\hline $\begin{array}{r}\text { Item } \\
\text { No. }\end{array}$ & \multicolumn{1}{|c|}{ Uraian } & \multicolumn{1}{|c|}{$\begin{array}{c}\text { Total Biaya } \\
(\mathrm{Rp})\end{array}$} & Persentase \\
\hline & & & \\
1 & Lantai & $32,105,126,796$ & $51.09 \%$ \\
2 & Fasad & $12,474,366,408$ & $19.85 \%$ \\
3 & Dinding & $10,628,064,457$ & $16.91 \%$ \\
4 & Plafon & $4,218,997,186$ & $6.71 \%$ \\
5 & Partisi & $1,486,420,726$ & $2.37 \%$ \\
6 & Sanitasi & $1,388,859,100$ & $2.21 \%$ \\
7 & Pintu \& Jendela & $535,733,100$ & $0.85 \%$ \\
\cline { 3 - 5 } & TOTAL & $62,837,567,773$ & $100.00 \%$ \\
\cline { 3 - 4 } & & & \\
\hline
\end{tabular}

\section{B. Analisa Fungsi}

Berdasarkan cost model diatas maka selanjutnya dilakukan analisa fungsi berdasarkan cost/worth yang didapat dari harga satuan tiap komponen pada masing-masing itemnya. Dengan menganalisa fungsi utama (basic function) dan fungsi penunjang (secondary function), sehingga dapat mengetahui perbandingan antara biaya dan nilai manfaat yang dibutuhkan untuk menghasilkan fungsi tersebut. Adapun untuk pekerjaan partisi, sanitasi, dan pintu\&jendela tidak dilakukan analisa fungsi karena data harga satuan pekerjaan dalam bentuk lump sum, sehingga sulit untuk dilakukan analisa fungsi. Tabel 2 merupakan hasil analisa fungsi lantai dan Tabel 3 merupakan analisa fungsi dinding luar.
Tabel 2.

Analisa Fungsi Lantai Analisa Fungsi

\begin{tabular}{|c|c|c|c|c|c|c|}
\hline \multirow{2}{*}{\multicolumn{7}{|c|}{$\begin{array}{l}\text { Item : Pekerjaan Lantai Area Mall, Sales } \\
\text { Fungsi : Alas Berpijak } \\
\end{array}$}} \\
\hline & & & & & & \\
\hline \multirow{2}{*}{ No } & \multirow{2}{*}{ Uraian } & \multicolumn{2}{|c|}{ Fungsi } & \multirow[b]{2}{*}{ Jenis } & \multirow{2}{*}{ Cost } & \multirow{2}{*}{ Worth } \\
\hline & & Kata Kerja & Kata Benda & & & \\
\hline 1 & $\begin{array}{l}\text { Plat Lantai } \\
(\mathrm{t}=20 \mathrm{~cm})\end{array}$ & Menahan & $\begin{array}{l}\text { Benda \& } \\
\text { Manusia }\end{array}$ & B & 502,232 & 502,232 \\
\hline 2 & $\begin{array}{l}\text { Screed } \\
(\mathrm{t}=35 \mathrm{~mm})\end{array}$ & Meratakan & Lantai & S & 68,100 & \\
\hline 3 & $\begin{array}{l}\text { Homogenious } \\
\text { Tile }(60 \times 60 \mathrm{~cm})\end{array}$ & Memperindah & Lantai & S & 411,100 & \\
\hline 4 & $\begin{array}{l}\text { Plint } \\
\text { Homogenious }\end{array}$ & Memperindah & Tepi lantai & S & 88,200 & \\
\hline \multicolumn{5}{|c|}{ Total } & \begin{tabular}{|l|}
$1,069,632$ \\
\end{tabular} & 502,232 \\
\hline \multicolumn{5}{|c|}{ Cost/Worth } & \multicolumn{2}{|c|}{$\frac{2.13}{2.13}$} \\
\hline
\end{tabular}

Tabel 3.

Analisa Fungsi Dinding Luar Analisa Fungsi

Item : Pekerjaan Dinding Luar

Fungsi : Melindungi dari cuaca

\begin{tabular}{|c|c|c|c|c|c|c|}
\hline \multirow{2}{*}{ No } & \multirow{2}{*}{ Uraian } & \multicolumn{2}{|c|}{ Fungsi } & \multirow{2}{*}{ Jenis } & \multirow{2}{*}{ Cost } & \multirow{2}{*}{ Worth } \\
\hline & & Kata Kerja & Kata Benda & & & \\
\hline 1 & $\begin{array}{l}\text { Pas. Bata } \\
\text { Ringan } \\
(\mathrm{t}=10 \mathrm{~cm})\end{array}$ & Penutup & Dinding & B & 240,000 & 240,000 \\
\hline 3 & Groving Baja & Penguat & Dinding & $\mathrm{S}$ & 98,900 & \\
\hline 2 & Plester & Meratakan & Pas. Bata & $\mathrm{S}$ & 109,000 & \\
\hline 5 & Cat exterior & Melapisi & Tembok & $\mathrm{S}$ & 41,200 & \\
\hline \multicolumn{5}{|r|}{ Total } & 489,100 & 240,000 \\
\hline & & & Cost/M & Vorth & \multicolumn{2}{|c|}{2.04} \\
\hline
\end{tabular}

Dari hasil analisa fungsi diatas jika didapatkan perbandingan Cost/Wort > 2 maka item pekerjaan tersebut mengindikasikan terdapat biaya yang tidak diperlukan, maka pekerjaan tersebut perlu dilakukan analisa pada tahap selanjutnya. Dimana, item pekerjaan dengan C/W $>2$ tersebut antara lain Item pekerjaan lantai mall, sales, dan cinema dengan $\mathrm{C} / \mathrm{W}$ sebesar 2,13 dan Item pekerjaan dinding luar dengan $\mathrm{C} / \mathrm{W}$ sebesar 2,04.

\section{Tahap Kreatif}

Pada tahap kreatif ini dilakukan pengumpulan alternatif pengganti dari masing-masing item pekerjaan yang terpilih dari tahap informasi. Pencarian alternatif didapat dari hasil survey melalui internet dan hasil diskusi dengan beberapa orang yang berpengalaman dalam bidangnya. Tabel 4 dan Tabel 5 adalah tabel alternatif pengganti pada pekerjaan lantai dan pekerjaan dinding luar. 
Tabel 4.

Alternatif Pekerjaan Lantai

\begin{tabular}{|c|l|}
\hline \multicolumn{2}{|l|}{ Item : Pekerjaan Lantai Area Mall, Sales dan Cinema } \\
\hline Fungsi : Memperindah lantai \\
\hline Kode & \multicolumn{1}{|c|}{ Alternatif } \\
\hline A0 & $\begin{array}{l}\text { Plat lantai }(\mathrm{t}=20 \mathrm{~cm}), \text { screed 3,5cm, homogenious tile } \\
60 x 60 \mathrm{~cm}, \text { plint homogenious }\end{array}$ \\
\hline A1 & $\begin{array}{l}\text { Plat lantai }(\mathrm{t}=20 \mathrm{~cm}), \text { screed } 2 \mathrm{~cm} \text { (mortar instan), marmer } \\
\text { lokal (60x60cm), plint marmer . }\end{array}$ \\
\hline A2 & $\begin{array}{l}\text { Plat lantai }(\mathrm{t}=20 \mathrm{~cm}), \text { screed } 2 \mathrm{~cm} \text { (mortar instan), lem, } \\
\text { parquet kayu jati 1,2x5x20cm, plint kayu. }\end{array}$ \\
\hline A3 & $\begin{array}{l}\text { Plat lantai }(\mathrm{t}=20 \mathrm{~cm}), \mathrm{screed} 2 \mathrm{~cm}(\text { mortar instan), lem, } \\
\text { linoleum tile }(50 \times 50 \mathrm{~cm}), \text { plint profile. }\end{array}$ \\
\hline A4 & $\begin{array}{l}\text { Plat lantai }(\mathrm{t}=20 \mathrm{~cm}), \mathrm{screed} 2 \mathrm{~cm}(\text { mortar instan), } \\
\text { ceramic tile }(60 \times 60 \mathrm{~cm}), \text { plint keramik }\end{array}$ \\
\hline
\end{tabular}

Tabel 5.

Alternatif Pekerjaan Dinding Luar

\begin{tabular}{|c|l|}
\hline \multicolumn{2}{|c|}{ Alternatif Penganti Pekerjaan Dinding Luar } \\
\hline \multicolumn{2}{|c|}{ Item: Pekerjaan Dinding Keliling } \\
\hline Fungsi : Membatasi Ruangan \\
\hline Kode & \multicolumn{1}{|c|}{ Alternatif } \\
\hline B0 & Pas. bata hebel ( $\mathrm{t}=10 \mathrm{~cm})$, groving, plester, cat exterior \\
\hline B1 & $\begin{array}{l}\text { Pas. bata merah ( } \mathrm{t}=7 \mathrm{~cm}), \text { groving, plester (mortar } \\
\text { instan), cat exterior }\end{array}$ \\
\hline B2 & Pas. bataton ( $\mathrm{t}=10 \mathrm{~cm})$, groving, plester (mortar instan), \\
\hline B3 & Pas. panel bata ringan ( $\mathrm{t}=10 \mathrm{~cm})$, groving, cat exterior \\
\hline
\end{tabular}

\section{Tahap Analisis}

Analisis biaya siklus hidup digunakan untuk menghitung alternatif berdasarkan kriteria biaya. Pada analisis biaya siklus hidup proyek, variable biaya yang diperhitungkan adalah :

1. Initial Cost : Biaya Konstruksi

2. Operational Cost : Biaya pengoperasian

3. Manitenance Cost : Biaya perawatan

4. Replacement Cost : Biaya penggantian material

5. Salvage Cost : Nilai sisa pada akhir umur Investasi.

Hasil perhitungan biaya daur hidur terdapat dalam Tabel 6 dan Tabel 7.

Tabel 6.

Total Biaya Daur Hidup Item Pekerjaan Lantai

\begin{tabular}{|c|c|c|c|c|c|c|}
\hline \multicolumn{7}{|c|}{ Tahap Analisa } \\
\hline \multicolumn{7}{|c|}{ Life Cycle Cost Analysis } \\
\hline \multirow{2}{*}{\multicolumn{7}{|c|}{$\begin{array}{l}\text { Item Pekerjaan : Lantai Area Mall, Sales dan Cinema } \\
\text { Umur Investasi : } 15 \text { tahun }\end{array}$}} \\
\hline & & & & & & \\
\hline \multicolumn{7}{|c|}{ MARR: $9 \%$} \\
\hline & & Desain awal (A0) & Alternatif 1(A1) & Alternatif $2(\mathrm{~A} 2)$ & Alternatif 3(A3) & Alternatif 4(A4) \\
\hline No. & Jenis Biaya & (Rp.) & (Rp.) & (Rp.) & (Rp.) & (Rp.) \\
\hline 1 & Initial cost & $10,939,249,391$ & $9,772,410,335$ & $10,741,502,302$ & $11,372,962,186$ & $9,075,223,633$ \\
\hline 2 & Operational & & & & & \\
\hline 3 & Maintenanc & 3,117,859,603 & 3,117,859,603 & $3,005,493,118$ & $1,852,701,237$ & $2,227,042,573$ \\
\hline 4 & $\begin{array}{l}\text { Replacement } \\
\text { cost }\end{array}$ & $127,283,969$ & $96,650,379$ & $2,086,084,886$ & 2,595,811,541 & $77,509,952$ \\
\hline 5 & $\begin{array}{l}\text { Salvage } \\
\text { value }\end{array}$ & 2,596,128,118 & $2,171,077,455$ & $2,201,157,921$ & 2,531,827,218 & 1,097,733,231 \\
\hline & $\begin{array}{l}\text { al Biaya Daur } \\
\text { up (Rp.) }=\end{array}$ & $11,588,264,845$ & $10,815,842,861$ & $13,631,922,385$ & $\mid 13,289,647,746$ & $10,282,042,927$ \\
\hline
\end{tabular}

Tabel 7

Total Biaya Daur Hidup Item Pekerjaan Dinding Luar Tahap Analisa

\begin{tabular}{|c|c|c|c|c|c|}
\hline \multicolumn{6}{|c|}{ Tahap Analisa } \\
\hline \multicolumn{6}{|c|}{ Life Cycle Cost Analysis } \\
\hline \multicolumn{6}{|c|}{ Item Pekerjaan : Dinding Luar } \\
\hline \multicolumn{6}{|c|}{ Umur Investasi : 15 tahun } \\
\hline \multicolumn{6}{|c|}{ MARR: 9\% } \\
\hline No. & Jenis Biaya & $\begin{array}{c}\text { Desain awal (B0) } \\
\text { (Rp.) }\end{array}$ & $\begin{array}{c}\text { Alternatif } 1 \text { (B1) } \\
\text { (Rp.) }\end{array}$ & $\begin{array}{c}\text { Alternatif } 2 \text { (B2) } \\
\text { (Rp.) }\end{array}$ & $\begin{array}{c}\text { Alternatif 3 (B3) } \\
\text { (Rp.) }\end{array}$ \\
\hline 1 & Initial cost & $5,182,725,813$ & $3,812,423,219$ & \begin{tabular}{|l|}
$4,643,982,787$ \\
\end{tabular} & $4,552,055,511$ \\
\hline 2 & $\begin{array}{l}\text { Operational } \\
\text { cost }\end{array}$ & 0 & 0 & 0 & \\
\hline 3 & Maintenance & 0 & 0 & 0 & 0 \\
\hline 4 & $\begin{array}{l}\text { Replacement } \\
\text { cost }\end{array}$ & $587,835,822$ & $587,835,822$ & $587,835,822$ & $587,835,822$ \\
\hline 5 & $\begin{array}{l}\text { Salvage } \\
\text { value }\end{array}$ & $1,347,513,911$ & $707,187,466$ & $1,330,857,142$ & 2,098,472,184 \\
\hline $\begin{array}{l}\text { Tot } \\
\text { Hid }\end{array}$ & $\begin{array}{l}1 \text { Biaya Daur } \\
\text { p (Rp.) = }\end{array}$ & $4,423,047,724$ & $3,693,071,576$ & $3,900,961,468$ & $3,041,419,149$ \\
\hline
\end{tabular}

\section{E. Analysis Hierarchy Process (AHP)}

AHP membantu untuk melakukan perbandingan satu lawan satu dari berbagai alternatif dalam satu kategori dengan menggukanan metode matrix.

\section{Perhitungan AHP Lantai}

Pekerjaan lantai yang baik adalah pekerjaan yang memiliki biaya murah, estetika indah, keawetan lama, mudah dilaksanakan, dan perawatan mudah. Hirarki pekerjaan lantai terdapat dalam Gambar 1.

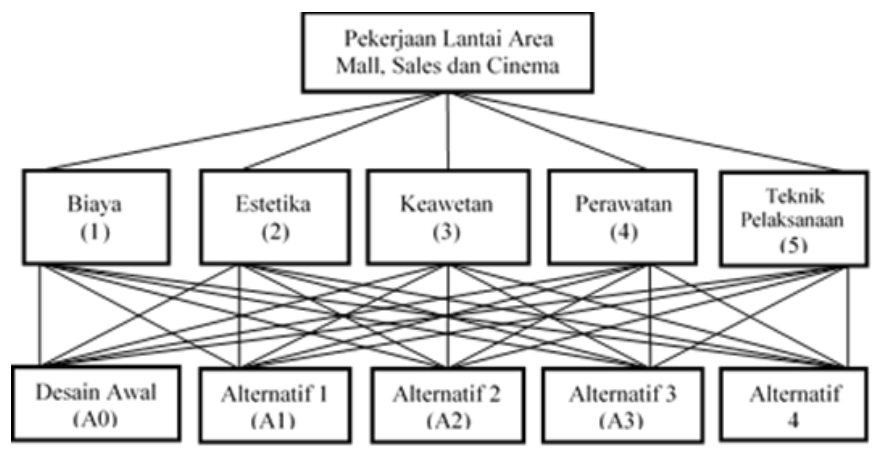

Gambar 1. Pohon Hirarki Pekerjaan Lantai

Dari hasil sintesa penilaian alternatif dengan kriteria didapatkan kesimpulan hasil perhitungan AHP, dimana yang mendapat nilai tertinggi maka terpilih sebagai alternatif desain lantai terbaik. Hasil AHP item pekerjaan lantai terdapat dalam Tabel 8.

Tabel 8.

Hasil AHP Item Pekerjaan Lantai

\begin{tabular}{|c|c|c|c|c|c|c|c|}
\hline \multirow{2}{*}{\multicolumn{2}{|c|}{ Tujuan }} & \multirow{2}{*}{ Bobot } & \multicolumn{5}{|c|}{ Alternatif } \\
\hline & & & A0 & A1 & A2 & A3 & A4 \\
\hline \multirow{5}{*}{ 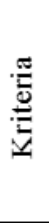 } & 1 & $50.28 \%$ & 0.0910 & 0.1281 & 0.0167 & 0.0241 & 0.2429 \\
\hline & 2 & $26.02 \%$ & 0.0350 & 0.1308 & 0.0677 & 0.0176 & 0.0091 \\
\hline & 3 & $13.44 \%$ & 0.0429 & 0.0624 & 0.0053 & 0.0053 & 0.0185 \\
\hline & 4 & $6.78 \%$ & 0.0176 & 0.0091 & 0.0024 & 0.0046 & 0.0341 \\
\hline & 5 & $3.48 \%$ & 0.0024 & 0.0012 & 0.0091 & 0.0175 & 0.0047 \\
\hline & $\Sigma=$ & $100.00 \%$ & $18.89 \%$ & $33.17 \%$ & $10.11 \%$ & $6.91 \%$ & $30.92 \%$ \\
\hline
\end{tabular}


Dari hasil AHP diketahui bahwa bobot masing-masing alternatif lantai berdasarkan kriteria adalah $\mathrm{A} 0=18,89 \%$, A1 $=33,17 \%$, A2 $=10,11 \%$, A3 $=6,91 \%$, A4 $=30,92 \%$. Hasil dari sintesa penilaian menunjukan bahwa alternatif 1 (A1) adalah alternatif terbaik karena mamiliki nilai tertinggi.

2. Perhitungan AHP Dindimg Luar

Pekerjaan dinding luar yang baik adalah pekerjaan yang memiliki kekuatan yang tinggi, biaya murah, dan mudah dilaksanakan. Hirarki pekerjaan dinding luar terdapat dalam Gambar 2.

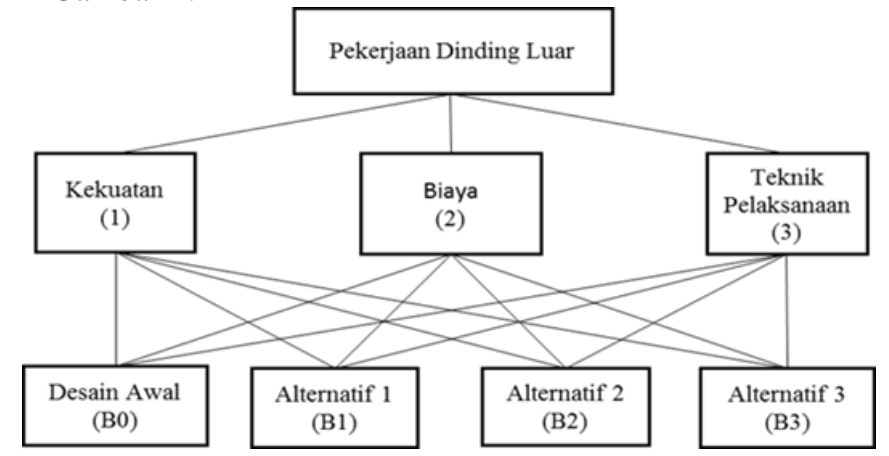

Gambar 2. Pohon Hirarki Pekerjaan Dinding Luar

Dari hasil sintesa penilaian alternatif dengan kriteria didapatkan kesimpulan hasil perhitungan AHP, dimana yang mendapat nilai tertinggi maka terpilih sebagai alternatif desain lantai terbaik. Hasil AHP item pekerjaan lantai terdapat dalam Tabel 9.

Tabel 9.

Hasil AHP Item Pekerjaan Dinding Luar

\begin{tabular}{|c|c|c|c|c|c|c|}
\hline \multirow{2}{*}{\multicolumn{2}{|c|}{ Tujuan }} & \multirow{3}{*}{$\begin{array}{l}\text { Bobot } \\
53.90 \% \\
\end{array}$} & \multicolumn{4}{|c|}{ Altematif } \\
\hline & & & \multirow{2}{*}{$\frac{\text { B0 }}{0.1341}$} & \multirow{2}{*}{$\begin{array}{c}\mathrm{B} 1 \\
0.0220\end{array}$} & \multirow{2}{*}{$\begin{array}{c}\text { B2 } \\
0.2945\end{array}$} & \multirow{2}{*}{$\begin{array}{c}\text { B3 } \\
0.0883\end{array}$} \\
\hline.$\stackrel{\pi}{=}$ & 1 & & & & & \\
\hline.$\stackrel{\Xi}{D}$ & 2 & $29.73 \%$ & 0.0166 & 0.0540 & 0.0292 & 0.1975 \\
\hline $\bar{z}$ & 3 & $16.38 \%$ & 0.0431 & 0.0093 & 0.0200 & 0.0914 \\
\hline \multicolumn{2}{|r|}{$\Sigma=$} & $100.00 \%$ & $19.39 \%$ & $8.53 \%$ & $34.36 \%$ & $37.72 \%$ \\
\hline
\end{tabular}

Dari hasil AHP diketahui bahwa bobot masing-masing alternatif dinding luar berdasarkan kriteria adalah B0 $=19,39 \%$, B1 $=8,53 \%, \quad B 2=34,36 \%, \quad B 3=37,72 \%$. Hasil dari sintesa penilaian menunjukan bahwa alternatif 2 (B2) adalah alternatif terbaik karena mamiliki nilai tertinggi

\section{F. Tahap Rekomendasi}

Tahap rekomendasi adalah tahap mengajukan rekomendasi dan alasan kenapa alternatif terpilih layak menggantikan desain awal. Alternatif dipilih dari alternatif terbaik hasil AHP. Rekomendasi tersebut sebagai berikut:

1. Pekerjaan Lantai :

- Desain Awal (A0) = plat lantai, screed 35mm, homogeneous tile $(60 \times 60 \mathrm{~cm})$, plint homogeneous tile.

- Rekomendasi $(\mathrm{A} 1)$ = plat lantai, screed 35mm, marmer lokal $(60 \times 60 \mathrm{~cm})$, plint marmer.
2. Pekerjaan Dinding Luar :

- Desain Awal (B0) = Pas. bata ringan, groving, plester, cat exterior

- Rekomendasi (B3) = Pas. panel bata ringan, groving, cat exterior.

Dari hasil penggantian desain awal dengan desain rekomendasi didapatkan total penghematan biaya konstruksi adalah sebesar Rp. 1,797,509,359 dari total biaya pekerjaan arsitektur sebesar Rp. 62,837,567,773. Sedangkan penghematan biaya daur hidup (LCC) adalah sebesar Rp. 2,154,050,559 (Tabel 10).

\begin{tabular}{|c|c|c|c|c|c|}
\hline \multicolumn{6}{|c|}{ Penghematan Biaya } \\
\hline \multicolumn{6}{|c|}{ Penghematan Biaya } \\
\hline \multirow{2}{*}{ No } & \multirow{2}{*}{ Jenis } & \multicolumn{2}{|c|}{ Biaya Konstruksi (Rp.) } & \multicolumn{2}{|c|}{ Biaya LCC (Rp.) } \\
\hline & & Desain Awal & Rekomendasi & Desain Awal & Rekomendasi \\
\hline 1 & Lantai & $10,939,249,391$ & $9,772,410,335$ & $11,588,264,845$ & $10,815,842,861$ \\
\hline 2 & Dinding luar & $5,182,725,813$ & $4,552,055,511$ & $4,423,047,724$ & $3,041,419,149$ \\
\hline & TOTAL & $16,121,975,204$ & $14,324,465,845$ & $16,011,312,569$ & $13,857,262,010$ \\
\hline \multicolumn{2}{|c|}{ PENGHEMATAN } & \multicolumn{2}{|c|}{$1,797,509,359$} & \multicolumn{2}{|c|}{$2,154,050,559$} \\
\hline
\end{tabular}

\section{KESIMPULAN/RINGKASAN}

Berdasarkan hasil analisa terhadap penerapan metode Rekayasa Nilai (Value Engineering) pada pekerjaan arsitektur pembangunan Proyek Transmart Carefour Padang, didapat hasil analisis Life Cycle Cost (LCC) terendah pada pekerjaan lantai adalah alternatif 4 (A4) dan pada pekerjaan dinding luar adalah alternatif 3 (B3). Hasil Analitycal Hierarchy Process (AHP), alternatif desain yang direkomendasikan untuk desain pekerjaan lantai adalah alternatif 1 (A1) yang terdiri dari "plat lantai, screed 20mm (mortar instan), marmer lokal (60x60 cm), dan plint marmer”, sedangkan untuk pekerjaan dinding luar alternatif terbaik adalah alternatif 3 (B3) terdiri dari "pasangan panel bata ringan $10 \mathrm{~cm}$, groving, dan cat exterior". Total penghematan biaya konstruksi yang diperoleh sebesar Rp. 1,797,509,359 dari total biaya pekerjaan arsitektur (Rp. $62,837,567,773)$.

\section{DAFTAR PUSTAKA}

[1] SAVE International, Value Methodology Standard. SAVE International, 2007.

[2] L. W. Zimmerman and G. D. Hart, Value engineering : a practical approach for owners, designers, and contractors. New York: Van Nostrand Reinhold, 1982.

[3] A. J. Dell'Isola, Value engineering : practical applications --for design, construction, maintenance \&amp; operations. Kingston, Mass. : R. S. Means Company, 1997.

[4] T. L. Saaty, "How to Make a Decision: The Analytic Hierarchy Process,” Interfaces (Providence)., vol. 24, pp. 19-43, 1994.

[5] A. J. Dell'Isola, Value engineering in the construction industry. New York: Van Nostrand Reinhold, 1982. 